\title{
ОПТИМИЗАЦИЯ ПАТОГЕНЕТИЧЕСКОЙ ТЕРАПИИ ИНСУЛЬТА
}

\author{
*Мирджураев Э.М., Бахадирова М.А., Эргашева Н.О. \\ Ташкентский институт усовершенствования врачей, Ташкент, Узбекистан
}

Были проведены исследования эффективности и безопасности применения антогониста глутаматных NMDA-рецепторов у больных в остром периоде инсульта. В качестве терапии был выбран препарат ПК-Мерц. На фоне лечения ПК-Мерц в основной группе отмечалась уменьшение неврологического дефицита по шкале NIHSS на $39,1 \%$ (р<0,005). При этом хороший эффект наблюдался у больных с легким инсультом (оценка по NIHSS<7 баллов) и не зависел от возраста и подтипа ишемического инсульта.

Ключевые слова: ишемический инсульт, лечение, препарат ПК-Мерц.

ведение. Сосудистые заболевания мозга
- актуальная медицинская и социальная
проблема. На сегодняшний день в мире около 9 млн. человек страдают цереброваскулярными заболеваниями, которые можно рассматривать как главную эпидемию XXI века. Основное место среди них занимают инсульты, каждый год поражающие от 5,6 до 6,6 млн. человек и уносящие 4,6 млн. жизней [1].

Наряду с высокой смертностью, социально значимыми являются и последствия инсультов - развитие тяжелой инвалидизации, менее $20 \%$ выживших возвращаются к прежней социальной и трудовой деятельности. Помимо этого, наносится огромный ущерб экономике, учитывая расходы на лечение, медицинскую реабилитацию, потери в сфере производства [1].

Самый высокий процент смертности приходится на первые 30 дней после развития инсульта. В среднем выживаемость в этот период составляет 70-85\% больных и зависит от типа инсульта: так, при геморрагическом инсульте выживает от 20-50\%, при инфаркте мозга - $85 \%$ [9].

В последние десятилетия основными терапевтическими стратегиями в остром периоде инсульта является реканлизация, реперфузия, нейро-протекция, ранняя вторичная профилактика $[2,3,4]$. Время эффективности терапевтических воздействий на мозговую ткань в зоне ишемической полутени (пенумбры) весьма вариабельно и зависит от особенностей коллатерального кровотока и состояния метаболизма головного мозга. Целью нейропротекции является предотвращение гибели нейронов в зоне ишемической полутени $[5,7,10,11]$.

При запуске патологического механизма *e-mail: emmir@bk.ru эксайтотоксичности происходит избыточное накопление внутриклеточного кальция, который и является конечным индуктором необратимой гибели нейронов. В этом случае эксайтотоксичность может быть нейтрализована блокадой NMDA-рецепторов [6,8,12].

Цель исследования. Изучение эффективности и безопасности применения антогониста глутаматных NMDA-рецепторов у больных в остром периоде инсульта.

Материал и методы. На базе реанимационного и неврологического отделения ГКБ№1 г.Ташкента для больных с острым нарушением мозгового кровообращения проведено исследование эффективности и безопасности применения антагониста глутаматных NMDA-рецепторов у больных в остром периоде инсульта. В качестве терапии был выбран препарат ПК-Мерц, который является неконкурентным антагонистом глутаматных NMDA-рецепторов с высокой селективностью и низкой аффинностью.

Все больные в исследовании были разделены на 2 группы. В основную группу были включены 23 больных (10 мужчин и 13 женщин) с ише-

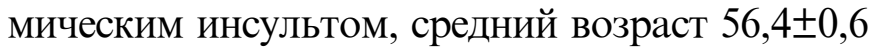
года, которым назначался ПК-Мерц. В контрольную группу вошли 10 больных (6 мужчин и 4 женщины), средний возраст $60,2 \pm 1,2$ года, они получали только базовую терапию. У большинства больных от начала заболеваний прошло от 24 до 48 ч. Пациенты с психотическими расстройствами исключены из исследования.

В основной группе ПК-Мерц назначался в виде инфузионного раствора 500 мл (200 мг) в сутки внутривенно капельно в 1-й день госпитализации, в большинстве случаев через 2448 часов от начала заболевания. Продолжи- 
тельность инфузии составляла 3ч. Курс лечения проводится в течении 10 дней. Сопутствующая терапия в обеих группах включала прием антиагрегантов, антикоагулянтов, статинов и гипотензивных средств.

Больным назначалось комплексное обследование: неврологичес-кое, нейровизуализиция - магнитно-резонансная томография головного мозга, дуплексное сканирование брахиоцефальных артерий (эхокардио-графическое исследование), определение содержания липидов и глюкозы крови, определение состояния свертывающей системы и реологических свойств крови, анализ крови RW и ВИЧ.

Наблюдение больных проводилось в период госпитализации и через 3 мес после инсульта, эффективность лечения оценивалась на 10-й день госпитализации и через 3 мес после начала заболевания. Оценка проводилась по шкале инсульта Национального института здоровья (NIHSS) (T.Brott, H. Adams. 1989), модифицированной шкале Рэнкина и индексу повседневной активности Бартел. Статистическая обработка достоверности различий в двух группах проводилась с помощью программного пакета Statistica 6,0 с использованием t-критерия Стьюдента и непараметрического U-критерия Манна-Уитни.

Результаты. В основной группе средняя

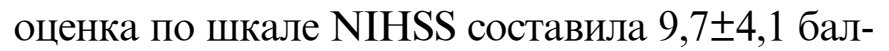

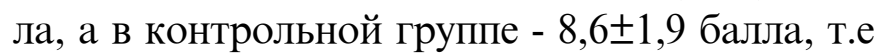
большинство больных были с легким и средней тяжести ишемическом инсультом. В соответствии с критериями TOAST патогенетические варианты инсульта в основной группе были распределены следующим образом: у $9(39,1 \%)$ больных - атеротромботический инсульт, у 8 (34,7\%) - кардиоэмболический инсульт, у 4 (17,3\%) - лакунарный. В контрольной группе у 4 (40\%) больных наблюдался атеротромботический инсульт, у 2 (20\%) - кардиоэболический, у 3 (30\%) - лакунарный. Факторы риска включали артериальную гипертензию 17 (73,9\%) больных основной группы и $8(80 \%)$ - контрольной группы, сахарный диабет 3 (13\%) и 1 (10\%) соответственно, мерцательную аритмию $8(34,7 \%)$ и 2 $(20 \%)$ соответственно. В анамнезе у $3(13 \%)$ больных основной группы инсульту предшест- вовали транзиторные ишемические атаки, у 1 (4,3\%) - инфаркт миокарда, у 1 (4,3\%) инсульт был повторным. В контрольной группе у 1 $(10 \%)$ больного инсульту предшествовали транзиторные ишемические атаки, у 1 (10\%) - инсульт был повторным. На фоне лечения ПКМерц в основной группе отмечалась уменьшение неврологического дефицита по шкале NIHSS на 39,1\% (p<0,005). При этом хороший эффект наблюдался у больных с легким инсультом (оценка по NIHSS <7 баллов) и не зависел от возраста и подтипа ишемического инсульта. В контрольной группе на 10-й день госпитализации оценка по шкале NIHSS снизилась на 24,4\%. Через 3 месяца после инсульта по шкале NIHSS неврологический дефицит в основной группе регрессировал на 58,7\% (p<0,001), в контрольной - на 41,8\%. При анализе динамики по шкале NIHSS отмечены достоверные различия между группами через 3 месяца после инсульта. При оценке по модифицированной шкале Рэнкина в основной группе на фоне лечения у 20\% больных отмечено полное функциональное восстановление, а у 50\% больных полное функциональное восстановление было достигнуто через 3 месяца. За время наблюдения выявлено достоверное снижение баллов по шкале Рэнкина в основной группе с $1,8 \pm 0,7$ до $0,5 \pm 0,2$ $(\mathrm{p}<0,005)$ и в меньшей степени в контрольной

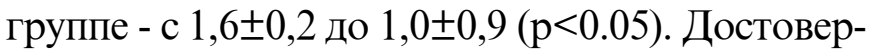
ные различия между группами получены только через 3 мес, $p<0.05$. Через 3 мес после инсульта индекс повседневной активности Бартел увеличился на 50\% в основной группе $(p<0.005)$ и на $41,1 \%$ в контрольной группе $(p<0.05)$ соответственно. Достоверных различий между группами по этому тесту выявлено не было. По результатам наблюдений, проведенных через 3 мес после инсульта, выживаемость больных в обеих группах составила $100 \%$. В большинстве случаев больные хорошо перено-сили инфузионную терапию препаратом ПК-Мерц. Побочные эффекты отмечались у 4 больных (у 2 возникло чувство тревоги, у 1 - тошнота и у 1 снижение артериального давления). Эти побочные эффекты не потребовали прекращения лечения. Серьезных нежелательных явлений зарегистрировано не было. 
Выводы: 1). Применения антогониста глутаматных NMDA-рецепторов ПК-Мерц в остром периоде инсульта в дозе 500 мл (200 мг) внутривенно капельно в течение 10 дней показало

\section{ЛИТЕРАТУРА}

1. Болезни нервной системы: Руководство для врачей: в 2-х т. - Т1, Под Ред. Яхно Н.Н., Штульмана Д.Р - 3-е издание, перераб и доп. - М.: Медицина, 2003.-744c.

2. Гусев Е.И., Скворцова В.И., Платонова И.А, Терапия ишемического инсульта // Consilium Medicum (спец. выпуск).2003;18-25.

3. Инсульт. Принципы диагностики, лечения и профилактики: краткое руководство для врачей. Под ред. Н.В.Верещагина, М. А. Пирадова, 3.А.Суслиной. М., 2002. стр-206. 4. Скворцова В.И., Механизмы повреждающего действия церебральной ишемии и новые терапевтические стратегии // Журнал неврологии и психиатрии 2003;9:20-25.

5. Суслина 3.А. Лечение ишемического инсульта. Лечение нервных болезней 2000;1:1:3-7.

6. Blanpied T.A., Clarke R.J., Johnson J.W. Amantadine inhibitis NMDA-receptors By accelerating channel closure during channel block // J neuro sci 2005;25:3312-3322.

7. Culmsee C., Junker V., Kremers W. et al. Combination свою эффективность и безопасность. 2). Применение данных доз по нашим наблюдениям, у больных с легкой и средней степенью тяжести инсульта улучшало прогноз заболевания.

therapy in ischemic stroke: synergistic neuroprotiye effects of memantine and clenbuterol // Stroke 2004;32:1197-1202. 8. Davis S.M., Lees Albers G.W. et al. Selfotel in Acute Ischemic Stroke: Possible Neurotoxic Effects of an NMDA Antagonist // Stroke 2000;31:347-354.

9. Evans A., Harraf F., Donaldson N., Lalit K. Randomized Controlled Study of Stroke Unit Care Versus Stroke Team in Different Stroke Subtypes // Stroke 2002;33:449-455.

10. Fisher M., Davalos A., Rogalewski et al. Toward a Multimodal Neuroprotective Treatment of Stroke // Stroke 2006;37:1129-1136.

11. Keith W. Muir Heterogeneity of Stroke Pathophysiology and Neuroprotictive Clinical Trial Design // Stroke 2002;33:1545-1550.

12. Lees, Dyker A.G., Sharma A. et al. Tolerability of the Low-Affinity, Use Dependent NMDA Antagonist ARR15896Ar in Stroke Patients : A Dose-Ranging Study // Stroke 2001;32:466-472.

\title{
XÜLASO
}

\section{INNSULTUN PATOGENETIK MÜALICCOSININ OPTIMIZZASIYYASI}

\author{
Mircurayev E.M., Bahadırova V.A., Erqaşeva N.O. \\ Daşkənt həkimlari təkmillaşdirmə institutu, Daşkənt, Özbəkistan
}

İnsultun kəskin dövründə xəstələrdə qlutamat NMDA-reseptorlarının antoqonistinin effektivliyi və təhlükəsizliyi tədqiq edilmişdir. Müalicə PK-Mers preparatı ilə aparılmışdır. PK-Mers ilə müalicə fonunda NIHSS şkalası ilə nevroloji defisitin əsas qrupda azalması qeyd edilmişdir - 39,1\% $(\mathrm{r}<0,005)$. Bu zaman yüngül insultu olan xəstələrdə yaxşı effekt alınmışdırş (NIHSS ilə qiymətləndirmə <7 bal) və yaşdan və işemik insultun alt tipindən asılı olmamışdır. Açar sözlər: işemik insult, müalicə, PK-Mers preparatı.

\section{SUMMARY}

\section{THE OPTIMIZATION PATHOGENETIC THERAPY OF A STROKE}

\author{
Mirdjuraev E.M., Bakhadirova M.A., Ergasheva N.O. \\ Tashkent institute of postgraduate medical education, Uzbekistan
}

There were conduced researches of efficiency and safety of application of the antagonist of glutamate NMDA-receptors at patients in the acute period of a stroke. As a medical therapy has been chosen PK-Mertz. Against the background of treatment in the main group it was noted reduction of neurologic deficiency on a scale NIHSS for $39.1 \%(\mathrm{p}<0.005)$. At the same time the good effect was observed at patients with a slight stroke (assessment on NIHSS $<7$ ). It doesn't depend on age and subtype of ischemic stroke.

Keywords: ischemic stroke, treatment, drug PK-Mertz.

Redaksiyaya daxil olub: 31.05 .2016

Çapa tövsiyə olunub: 20.06 .2016

Rəyçi: prof. R.K.Şiraliyeva 